\title{
Hydration of calcium aluminate cement blended with anhydrite
}

\section{Gwenn Le Saoût}

Empa, Swiss Federal Laboratories for Materials Science and Technology, Laboratory for Concrete and Construction Chemistry, Dübendorf,

Switzerland; presently IMT Mines Alès, Centre des Matériaux de l'École des mines d'Alès (C2MA), Alès, France (corresponding author:

gwenn.le-saout@mines-ales.fr) (Orcid:0000-0002-2761-0584)

Barbara Lothenbach

Empa, Swiss Federal Laboratories for Materials Science and Technology, Laboratory for Concrete and Construction Chemistry, Dübendorf,

Switzerland
Pascal Taquet

Kerneos Research \& Technical Center, Vaulx-Milieu, France Hervé Fryda

Kerneos Research \& Technical Center, Vaulx-Milieu, France

Frank Winnefeld

Empa, Swiss Federal Laboratories for Materials Science and Technology, Laboratory for Concrete and Construction Chemistry, Dübendorf, Switzerland

Calcium aluminate cements (CACs) are used in combination with calcium sulfates as binders in self-levelling mortars. The influence of commercial CAC/anhydrite ratio on the solid phase assemblage and pore solution at water to binder $(\mathrm{w} / \mathrm{b})$ ratios of 0.40 and $\mathbf{0 . 7 2}$ was investigated between $\mathbf{1 . 5} \mathrm{h}$ and $91 \mathrm{~d}$ of hydration using a multi-method approach including $x$-ray diffraction, thermogravimetric analysis and thermodynamic calculations. The reduction of the extent of hydration at the lower w/b ratio can be explained by a lack of water for complete hydration and lack of space. In the system with a CAC/anhydrite weight ratio of 1, ettringite and $\mathrm{AH}_{3}$ were the main hydration products, whereas in the case of a CAC/anhydrite ratio of $2 \cdot 3$, in addition to ettringite and $\mathrm{AH}_{3}$, monosulfate was present along with strätlingite and at a later age. In contrast to the thermodynamic modelling results, anhydrite persisted even at low calcium sulfate contents as the precipitation of $\mathrm{AH}_{3}$ around the anhydrite grains seemed to lead to a chemical blocking.

\section{Introduction}

Calcium aluminate cements (CACs) can be used in combination with different calcium sulfate sources as binders of selflevelling mortars for under- and overlayments or screeds. These types of binder, together with special admixtures, make fast drying and rapid strength development possible, as well as shrinkage compensation of the cured mortar (Lutz and Bayer, 2010). The rapid strength development and expansive behaviour are related to the formation of ettringite according to the following reaction (standard cement chemistry notation is used: $\mathrm{C}=$ calcium oxide $(\mathrm{CaO}), \mathrm{A}=$ aluminium oxide $\left(\mathrm{Al}_{2} \mathrm{O}_{3}\right)$, $\mathrm{F}=$ iron oxide $\left(\mathrm{Fe}_{2} \mathrm{O}_{3}\right), \mathrm{S}=$ silicon dioxide $\left(\mathrm{SiO}_{2}\right), \overline{\mathrm{S}}=$ sulfur trioxide $\left(\mathrm{SO}_{3}\right)$ and $\mathrm{H}=$ water $\left.\left(\mathrm{H}_{2} \mathrm{O}\right)\right)$.

I. $3 \mathrm{CA}+3 \mathrm{C} \overline{\mathrm{S}}+38 \mathrm{H} \rightarrow \mathrm{C}_{6} \mathrm{AS}_{3} \mathrm{H}_{32}+2 \mathrm{AH}_{3}$

Monocalcium aluminate CA is the main component of CAC and the sulfate necessary for ettringite formation is provided by blending $\mathrm{CAC}$ with calcium sulfates such as anhydrite $(\mathrm{C} \overline{\mathrm{S}})$, hemihydrate, gypsum or mixes thereof (Glasser et al., 2001). As previously reported in literature (see Bizzozero et al. (2014) and references therein), depending on the CA to sulfate ratio, the phase assemblage changes as shown in Figure 1 (derived from thermodynamic calculations of the stable hydrate phases, see section on 'Thermodynamic modelling'). Since ettringite is a water-rich phase, the water demand for complete hydration is considerably higher than for
Portland cement. The highest water demand in the $\mathrm{CA}-\mathrm{C} \overline{\mathrm{S}}$ system corresponds to the maximum ettringite formation (Reaction I). It corresponds to an anhydrite mass fraction of 0.46 , and a water to binder $(\mathrm{w} / \mathrm{b})$ weight ratio of 0.78 is needed for a complete hydration. In Figure 1 , a w/b ratio of 0.80 is used to ensure excess water in the system (the minimum $w / b$ required for complete hydration of $\mathrm{CA}$ is indicated on the right-hand axis of the figure). However, materials used for repair or flooring screeds have low w/b ratios in order to achieve high early strengths and are likely to retain much unhydrated binder (Glasser et al., 2001). In commercial CACs, the presence of small amounts of silicon dioxide from impurities in the raw meal may lead to the formation of dicalcium silicate $\left(\beta-\mathrm{C}_{2} \mathrm{~S}\right)$ and gehlenite $\left(\mathrm{C}_{2} \mathrm{AS}\right)$ (Odler, 2000). The hydraulic reactivity of $\beta-\mathrm{C}_{2} \mathrm{~S}$ changes the phase assemblage and thermodynamic calculations indicate, in the presence of sufficient silicon dioxide, the possible formation of siliceous hydrogrossular $\left(\mathrm{C}_{3} \mathrm{AS}_{x} \mathrm{H}_{6-x}\right)$ and strätlingite $\left(\mathrm{C}_{2} \mathrm{ASH}_{8}\right)$, which are more stable than $\mathrm{C}_{3} \mathrm{AH}_{6}$ (Lothenbach, 2014). Both phases have been observed experimentally in, for example, CAC blended with silica fume or fly ash (Hidalgo Lopez et al., 2008).

In work reported in this paper, the influence of the CAC/anhydrite ratio and the $w / b$ ratio on the kinetics of hydration and phase assemblage of a commercial CACanhydrite blend was investigated. A thermodynamic model was used to predict the composition of the solid phases and the results were compared with experimental data. 


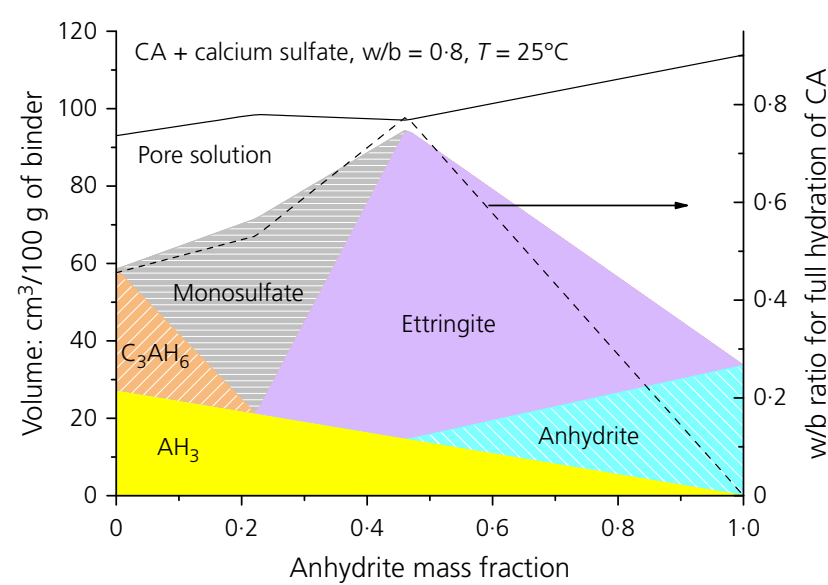

Figure 1. Thermodynamic phase assemblage modelling of the hydration of CA blended with anhydrite as a function of anhydrite weight fraction in the unhydrated blended cement at $\mathrm{w} / \mathrm{b}=0.80$. Volume expressed as $\mathrm{cm}^{3} / 100 \mathrm{~g}$ unhydrated blended cement (left-hand axis). Minimum w/b ratio required for complete hydration of CA is shown on the right-hand axis

\section{Experimental details}

\section{Materials}

The chemical and mineralogical compositions of the raw materials are listed in Table 1. A commercial CAC (labelled T) and a micronised natural anhydrite (labelled A) were used. Quantitative x-ray diffraction (XRD) was performed by Rietveld analysis (Füllmann et al., 1999). In order to improve the Rietveld analysis of the CAC and especially the detection of minor phases, selective dissolution was carried out according to the protocols proposed by Götz-Neunhoeffer (2003).
The proportions of the raw materials in the four mixes studied are reported in Table 2. Two different anhydrite mass fractions were investigated in order to cover the system (see Figure 1) with ettringite, monosulfate, $\mathrm{AH}_{3}$ (samples $\mathrm{T} 3$ with anhydrite mass fraction of $0 \cdot 3$ ) and with ettringite, $\mathrm{AH}_{3}$ (samples $\mathrm{T} 5$ with anhydrite mass fraction of $0 \cdot 5$ ). Two w/b weight ratios were also considered: $w / b=0 \cdot 72$ to ensure excess water in the system (W7) and $w / b=0.40$ to retain much anhydrous binder (W4).

\section{Hydration experiments}

The pastes were formulated to have a w/b mass ratio of 0.40 (samples labelled T3W4 and T5W4) and 0.72 (samples labelled T3W7 and T5W7). Samples consisting of $100 \mathrm{~g}$ of binder and the appropriate amount of water were mixed twice for $90 \mathrm{~s}$ according to EN-196-3 (AFNOR, 2009) with a high-shear blender (except for conduction calorimetry).

\section{Conduction calorimetry}

A conduction calorimeter (TAM Air, Thermometric AB, Sweden) operating at $20^{\circ} \mathrm{C}$ was used to determine the hydration heat flow. Admix ampoules described by Wadsö (2005) were used to enable internal mixing, which allows study of the very early hydration reactions.

\section{Analysis of solid phases}

Plastic bottles of volume $12 \mathrm{ml}$ were completely filled with the fresh pastes; the bottles were sealed and then stored at $20^{\circ} \mathrm{C}$. Prior to thermogravimetric analysis (TGA) and XRD analyses, hydration was stopped after 3, 5, 12 and $18 \mathrm{~h}$ and 1, 3, 28 and $91 \mathrm{~d}$ by immersing small pieces, each around $2-3 \mathrm{~mm}^{3}$, for

Table 1. Mineralogical and chemical compositions of the CAC (T) and micronised natural anhydrite (A). Mineralogical composition determined by XRD/Rietveld analysis. Chemical analysis by $x$-ray fluorescence (except sulfur trioxide) measured with a Leco apparatus

\begin{tabular}{|c|c|c|c|c|c|}
\hline & $\mathrm{T}: \mathrm{wt} \%$ & A: wt \% & & T:wt\% & A: wt \% \\
\hline CA & $54 \cdot 6$ & - & Sodium oxide $\left(\mathrm{Na}_{2} \mathrm{O}\right)$ & 0.07 & $0 \cdot 12$ \\
\hline Ferrite $\left(C_{4} A F\right)$ & $10 \cdot 3$ & - & Magnesium oxide (MgO) & 0.47 & $1 \cdot 44$ \\
\hline Ferrite $\left(C_{2} A F\right)$ & $3 \cdot 0$ & - & Aluminium oxide $\left(\mathrm{Al}_{2} \mathrm{O}_{3}\right)$ & $39 \cdot 75$ & 0.62 \\
\hline Gehlenite $\left(C_{2} A S\right)$ & $9 \cdot 7$ & - & Silicon dioxide $\left(\mathrm{SiO}_{2}\right)$ & $4 \cdot 35$ & $2 \cdot 33$ \\
\hline Perovskite $(\mathrm{CT})$ & $6 \cdot 5$ & - & Phosphorus pentoxide $\left(\mathrm{P}_{2} \mathrm{O}_{5}\right)$ & $0 \cdot 16$ & 0.03 \\
\hline Perovskite $\left(\mathrm{C}_{3} \mathrm{FT}\right)$ & $1 \cdot 1$ & - & Sulfur trioxide $\left(\mathrm{SO}_{3}\right)$ & $0 \cdot 12$ & $52 \cdot 07$ \\
\hline Magnetite $\left(\mathrm{Fe}_{3} \mathrm{O}_{4}\right)$ & $6 \cdot 3$ & - & Potassium oxide $\left(\mathrm{K}_{2} \mathrm{O}\right)$ & $0 \cdot 11$ & $0 \cdot 2$ \\
\hline Belite $\left(C_{2} S\right)$ & $4 \cdot 3$ & - & Calcium oxide $(\mathrm{CaO})$ & $36 \cdot 53$ & 38.61 \\
\hline Phase Q & $2 \cdot 3$ & - & Titanium dioxide $\left(\mathrm{TiO}_{2}\right)$ & $1 \cdot 83$ & - \\
\hline Mayenite $\left(C_{12} A_{7}\right)$ & $1 \cdot 6$ & - & Manganese(III) oxide $\left(\mathrm{Mn}_{2} \mathrm{O}_{3}\right)$ & 0.26 & - \\
\hline Ye'elimite $\left(C_{4} A_{3} \bar{S}\right)$ & 0.2 & - & Iron(III) oxide $\left(\mathrm{Fe}_{2} \mathrm{O}_{3}\right)$ & $16 \cdot 15$ & 0.24 \\
\hline Anhydrite & - & $88 \cdot 1$ & $\mathrm{LOI}^{\mathrm{b}}$ & 0.2 & $3 \cdot 7$ \\
\hline Gypsum & - & $3 \cdot 6$ & $d_{10}: \mu m^{c}$ & $3 \cdot 2$ & $2 \cdot 5$ \\
\hline Dolomite & - & $6 \cdot 8$ & $d_{50}: \mu \mathrm{m}$ & $18 \cdot 0$ & $12 \cdot 2$ \\
\hline Quartz & - & $1 \cdot 5$ & $d_{90}: \mu \mathrm{m}$ & $63 \cdot 0$ & $45 \cdot 0$ \\
\hline $\mathrm{Na}_{2} \mathrm{O}_{\text {soluble }}{ }^{\mathrm{a}}$ & 0.09 & $<0.01$ & Blaine fineness: $\mathrm{m}^{2} / \mathrm{kg}$ & 3090 & 4080 \\
\hline $\mathrm{K}_{2} \mathrm{O}_{\text {soluble }}{ }^{\mathrm{a}}$ & 0.03 & $<0.01$ & Density: $\mathrm{g} / \mathrm{cm}^{3}$ & $3 \cdot 22$ & $2 \cdot 90$ \\
\hline
\end{tabular}

${ }^{a}$ Readily soluble alkalis calculated from concentrations of alkalis measured in the solution after 5 min of agitation at a water to raw materials of 10

boss on ignition measured until $950^{\circ} \mathrm{C}$ by TGA

${ }^{\mathrm{C}}$ Particle size determined by laser granulometry 
Table 2. Contents of CAC (T) and micronised natural anhydrite (A) in the four mixes

\begin{tabular}{lccc} 
& T: $\mathbf{g}$ & A: $\mathbf{g}$ & Water: $\mathbf{g}$ \\
\hline T5W4 & 50 & 50 & 40 \\
T5W7 & 50 & 50 & 72 \\
T3W4 & 70 & 30 & 40 \\
T3W7 & 70 & 30 & 72
\end{tabular}

$30 \mathrm{~min}$ in about $50 \mathrm{ml}$ isopropanol and rinsing twice with diethyl ether. TGA (Mettler Toledo, TGA/SDTA 851e) was performed using about $60 \mathrm{mg}$ of powder at a heating rate of $20^{\circ} \mathrm{C} / \mathrm{min}$ under nitrogen between $30^{\circ} \mathrm{C}$ and $980^{\circ} \mathrm{C}$. The amount of bound water was deduced from the weight losses between $40^{\circ} \mathrm{C}$ and $550^{\circ} \mathrm{C}$.

XRD data were collected using a PANalytical X'Pert Pro MPD diffractometer in a $\theta-2 \theta$ configuration using an incident beam monochromator employing $\mathrm{CuK}_{\alpha 1}$ radiation with a fixed divergence slit size of $0.5^{\circ}$ and a rotating sample stage. The samples were scanned between $5^{\circ}$ and $70^{\circ}$ with the $X^{\prime}$ Celerator detector. The Rietveld analysis was performed with the X'Pert High Score Plus software (version 2.1). The Rietveld refinement of the anhydrous phases and the ICSD (inorganic crystal structure database) codes of the structural data are given in Table 3. Once refinements of the raw materials had been done, the unit cell dimensions and shape parameters of the anhydrous phases were kept constant during refinement of the hydrated pastes. For the hydrated pastes, an external standard calcium fluoride $\left(\mathrm{CaF}_{2}\right)$ ( $G$-factor approach) was used to quantify the x-ray amorphous part (Jansen et al., 2011a, 2011b; O'Connor and Raven, 1988; Stabler et al., 2011). The mass attenuation coefficients of the samples were determined by $\mathrm{x}$-ray fluorescence analysis from the data in Table 1 , taking into account the amount of bound water determined by TGA. Due to the hydration reactions, water is bound in the hydrates so the total amount of solids increases. In order to correct for this dilution effect, the amount of bound water determined by TGA was deduced, so that the results always refer to the mass of unhydrated binder.

For the microscopic investigations, slices of hydrated samples were cut, immediately immersed in isopropanol for $3 \mathrm{~d}$ and then subsequently dried at $40^{\circ} \mathrm{C}$ for $24 \mathrm{~h}$. They were then impregnated using a low*viscosity epoxy resin and polished down to $0 \cdot 25 \mu \mathrm{m}$ using diamond pastes. The obtained polished sections were further coated with carbon $(\sim 5 \mathrm{~nm})$ and examined using a scanning electron microscope (SEM) (Phillips FEG-XL30) coupled with an energy dispersive X-ray spectroscopy (EDX) analyser (EDAX). The EDX point analyses were used to determine the elemental compositions of the hydrate assemblage. The analyses were carried out using an acceleration voltage of $15 \mathrm{kV}$ to ensure a good compromise between spatial resolution and adequate excitation of the $\mathrm{FeK}_{\alpha}$ peak. Over 60 points (EDX spots) per sample were analysed.

\section{Analysis of pore solutions}

The pore solution analyses were performed only on the samples with the high w/b ratio of 0.72 (T3W7 and T5W7) in order to be able to extract some solution from the samples also at later hydration times. For pore solution extraction, samples consisting of $1 \mathrm{~kg}$ binder and $0.72 \mathrm{~kg}$ water were mixed according to the EN-196-3 (AFNOR, 2009) standard. The pastes were cast in $500 \mathrm{ml}$ polyethylene bottles, sealed and stored in a thermostatic bath. Pore solutions during the first hours were collected by pressure filtration. At a hydration time of $1 \mathrm{~d}$ and beyond, pore fluids were extracted using the steel die method with pressures up to $530 \mathrm{~N} / \mathrm{mm}^{2}$ (Lothenbach and Winnefeld, 2006). In all cases, the solutions were immediately filtered using $0 \cdot 45 \mu \mathrm{m}$ nylon filters. $5 \mathrm{ml}$ aliquots were diluted with $20 \mathrm{ml}$ Milli-Q water. The total concentrations of the element analysed were determined using ion chromatography (Dionex ICS-3000). The $\mathrm{pH}$ was measured using a Knick pH meter equipped with a Knick SE 100 electrode calibrated against potassium hydroxide $(\mathrm{KOH})$ solutions of known concentrations.

\section{Thermodynamic modelling}

Thermodynamic modelling was used to calculate the effective saturation indices of various hydrate phases that could potentially form in the pastes, using the measured compositions of the pore solution, as well as to model the hydration processes. The Gibbs free energy minimisation software GEMS v.3 was used (see GEMS, 2017; Kulik et al., 2013; Wagner et al., 2012). The thermodynamic data for aqueous species and many solids were taken from the PSI-GEMS thermodynamic database (Hummel et al., 2002), while the solubility products for cement minerals were taken from the Cemdata 14.01 database (see Dilnesa et al., 2014; EMPA, 2017; Lothenbach et al., 2012; Matschei et al., 2007).

The saturation index with respect to a solid is given by $\log$ $\left(\mathrm{IAP} / K_{\mathrm{s} 0}\right)$, where IAP is the ion activity product, calculated from activities derived from the concentrations determined in the solution, and $K_{\mathrm{s} 0}$ is the solubility product of the respective solid. A positive saturation index implies oversaturation while a negative value indicates undersaturation with regard to the respective solid. All calculated saturation indices refer to the solubility products of the solids as given by Lothenbach et al. (2008, 2012) and Matschei et al. (2007). As silicon (Si) concentrations were below detection limit $(<0 \cdot 1 \mathrm{mmol} / \mathrm{l})$, a value of $0 \cdot 1 \mathrm{mmol} / \mathrm{l}$ was assumed in order to calculate the effective saturation indices of strätlingite. The given saturation index of strätlingite represents its upper limit. As the use of saturation indices can be misleading when comparing phases that dissociate into a different number of ions, 'effective' saturation indices were calculated by dividing the saturation indices 
Table 3. References of the different phases used for Rietveld analysis

\begin{tabular}{lllll}
\hline Phase & Formula & Crystal system & \multicolumn{1}{c}{ ICSD } & Reference \\
\hline Calcium monoaluminate & $\mathrm{CaOAl}_{2} \mathrm{O}_{3}$ & Monoclinic & 260 & Hörkner and Müller-Buschbaum (1976) \\
Ferrite & $\mathrm{Ca}_{2} \mathrm{AlFeO}_{5}$ & Orthorhombic & 9197 & Colville and Geller (1971) \\
Ferrite & $\mathrm{Ca}_{2} \mathrm{Fe}_{2} \mathrm{O}_{5}$ & Orthorhombic & 98822 & Redhammer et al. (2004) \\
Gehlenite & $\mathrm{Ca}_{2} \mathrm{Al}_{2} \mathrm{SiO}_{7}$ & Tetragonal & 67689 & Swainson et al. (1992) \\
Perovskite & $\mathrm{CaTiO}_{3}$ & Orthorhombic & 62149 & Sasaki et al. (1987) \\
Perovskite & $\mathrm{Ca}_{3} \mathrm{TiFe}_{2} \mathrm{O}_{8}$ & Orthorhombic & 203100 & Rodriguez-Carvajal et al. (1989) \\
Magnetite & $\mathrm{Fe}_{3} \mathrm{O}_{4}$ & Cubic & 84611 & Sasaki (1997) \\
Belite & $\mathrm{Ca}_{2} \mathrm{SiO}_{4}$ & Monoclinic & 79550 & Tsurumi et al. (1994) \\
Phase Q & $\mathrm{Ca}_{20} \mathrm{Al}_{26} \mathrm{Mg}_{3} \mathrm{Si}_{3} \mathrm{O}_{68}$ & Orthorhombic & 26353 & Hanic et al. (1980) \\
Mayenite & $\mathrm{Ca}_{12} \mathrm{Al}_{14} \mathrm{O}_{33}$ & Cubic & 62040 & Christensen and Lehmann (1984) \\
Ye'elimite & $\mathrm{Ca}_{4} \mathrm{Al}_{6} \mathrm{O}_{12}\left(\mathrm{SO}_{4}\right)$ & Cubic & 9560 & Saalfeld and Depmeier (1972) \\
Anhydrite & $\mathrm{CaSO}_{4}$ & Orthorhombic & 40043 & Hawthorne and Ferguson (1975) \\
Gypsum & $\mathrm{CaSO}_{4} 2 \mathrm{H}_{2} \mathrm{O}$ & Monoclinic & 151692 & De la Torre et al. (2004) \\
Dolomite & $\left.\mathrm{CaMg}_{2} \mathrm{CO}_{3}\right)_{2}$ & Trigonal & 31335 & Effenberger et al. (1983) \\
Quartz & $\mathrm{SiO}_{2}$ & Rhombohedral & 200721 & Jorgensen (1978) \\
Kuzelite & $\mathrm{Ca}_{4} \mathrm{Al}_{2} \mathrm{SH}_{24} \mathrm{O}_{22}$ & Trigonal & 100138 & Allmann (1977) \\
Ettringite & $\mathrm{Ca}_{6} \mathrm{Al}_{2} \mathrm{~S}_{3} \mathrm{H}_{64} \mathrm{O}_{50}$ & Trigonal & 155395 & Götz-Neunhoeffer and Neubauer (2004) \\
& & & &
\end{tabular}

by the number of ions participating in the reactions to form the solids (Lothenbach, 2010).

Thermodynamic modelling of the hydration of the four systems was carried out in a similar manner as described previously, for example for calcium sulfoaluminate cement (Le Saout et al., 2013; Pelletier et al., 2010; Winnefeld and Lothenbach, 2010). By combining an empirical model of the experimental data that describes the dissolution of the clinker phases as a function of time with a thermodynamic equilibrium model, the amount of hydrates formed can be calculated as a function of time.

\section{Results and discussion}

Thermodynamic modelling of hydrated cements

Figure 2 shows the thermodynamic modelling of the CAC blended with anhydrite as a function of natural anhydrite mass fraction ratio in the anhydrous blended cement. Complete hydration of the raw materials was assumed apart from for dolomite and quartz in the natural anhydrite and $\mathrm{CT}, \mathrm{C}_{3} \mathrm{FT}, \mathrm{C}_{2} \mathrm{AF}, \mathrm{Fe}_{3} \mathrm{O}_{4}$ and $\mathrm{C}_{2} \mathrm{AS}$ in the $\mathrm{CAC}$ as they are known to have low dissolution kinetics at ambient temperature (Pöllmann, 2001). The formation of gibbsite was supressed in all calculations, as well as siliceous hydrograndite $\mathrm{Ca}_{3}\left(\mathrm{Al}_{x} \mathrm{Fe}_{1-x}\right)_{2}\left(\mathrm{SiO}_{4}\right)_{3-y}(\mathrm{OH})_{4 y}$ and gypsum as they were not observed experimentally during the study period. As previously reported and presented later in the paper, the formation of $\mathrm{AH}_{3}$ with small crystalline size was observed, which differentiates it from well-crystalline gibbsite (Lothenbach et al., 2012).

For a $w / b=0 \cdot 72$, the equilibrium pore solution compositions and phase assemblages are presented in Figures 2(a) and 2(b). The thermodynamic modelling showed, between an anhydrite mass fraction of 0 and about $0 \cdot 2$, a pore solution in equilibrium with $\mathrm{C}_{3} \mathrm{AH}_{6}$, monosulfate, strätlingite, $\mathrm{AH}_{3}$ and $\mathrm{FH}$. At a mass fraction of anhydrite $\geq 0 \cdot 2, \mathrm{C}_{3} \mathrm{AH}_{6}$ was no longer stable while ettringite became thermodynamically stable; the

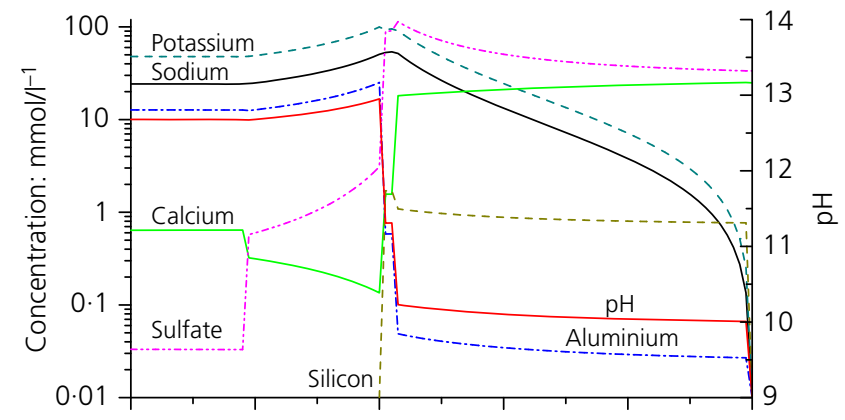

(a)

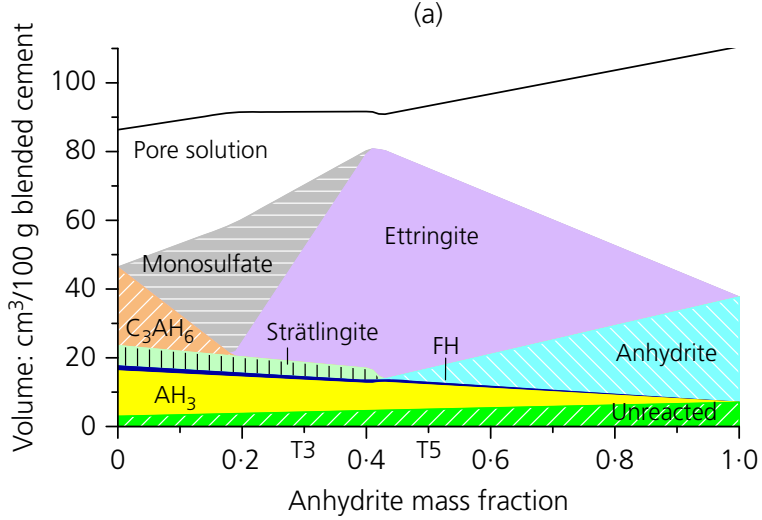

(b)

Figure 2. Thermodynamic modelling of the hydration of CAC blended with anhydrite as a function of the anhydrite mass fraction in the unhydrated blended cement. Pore solution $(\mathrm{w} / \mathrm{b}=0.72)(\mathrm{a})$ and phase assemblage modelling $(\mathrm{b})$ at $\mathrm{w} / \mathrm{b}=0.72$. Volume expressed as $\mathrm{cm}^{3} / 100 \mathrm{~g}$ unhydrated blended cement 


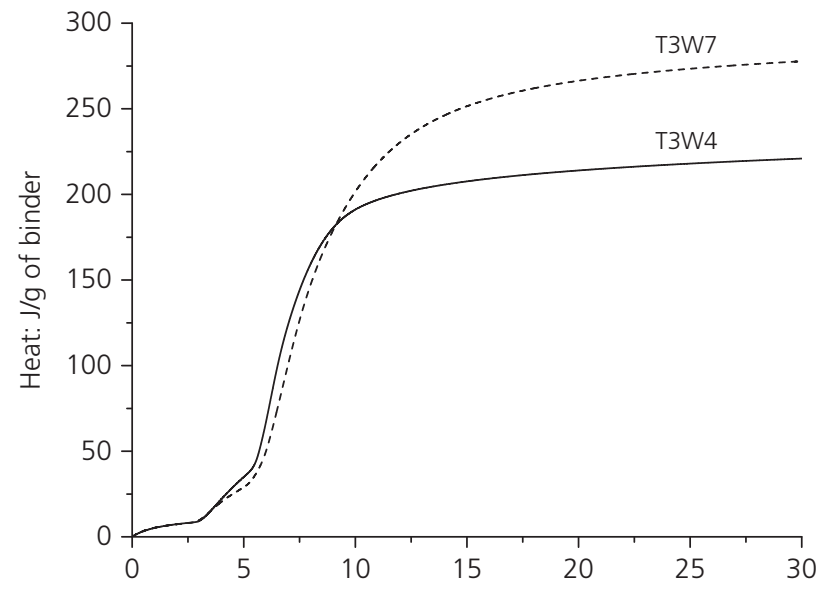

(a)

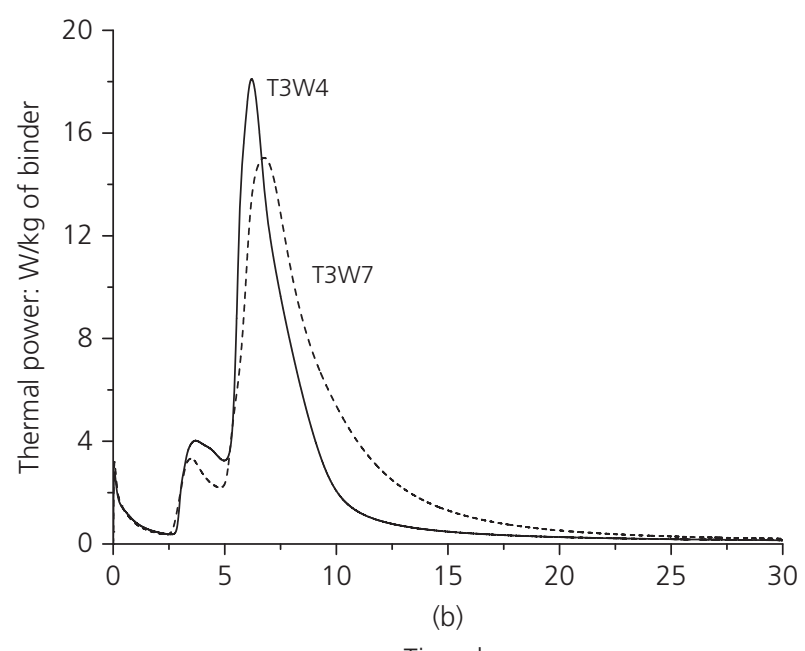

Time: $h$
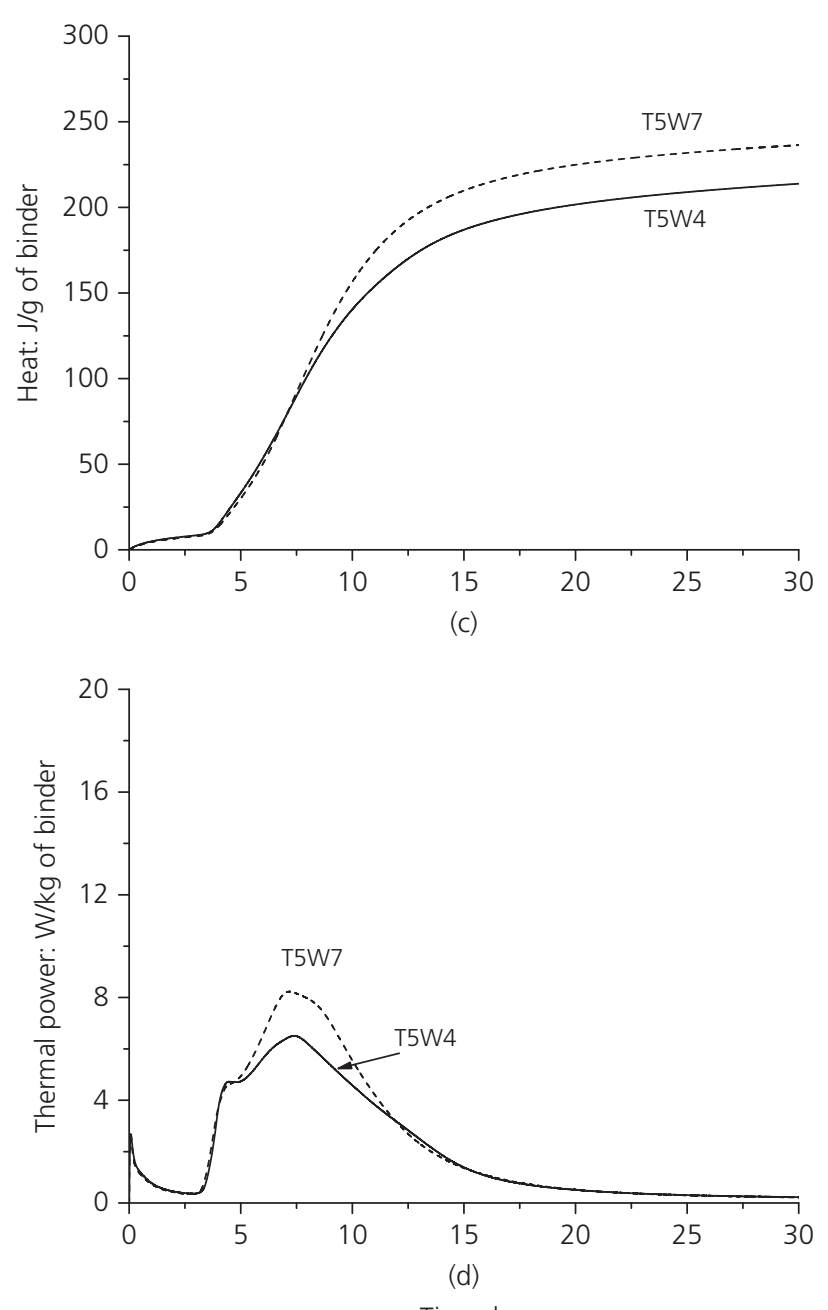

Time: $\mathrm{h}$

Figure 3. Cumulative heat of cement pastes ((a) and (c)) and heat flow development ((b) and (d)) between 0 and $30 \mathrm{~h}$

concentration of sulfate increased. Another threshold occurred at an anhydrite mass fraction of about 0.4 where strätlingite and monosulfate were not stable anymore and the solution was saturated with respect to anhydrite. The concentrations of calcium, sulfate and silicon increased strongly while aluminium concentrations and $\mathrm{pH}$ decreased. Two systems on either side of the threshold at an anhydrite mass fraction of 0.4 were investigated: $0 \cdot 3$ (T3) and 0.5 (T5) with w/b ratios of 0.40 and $0 \cdot 72$. Based on the model, at a w/b ratio of $0 \cdot 40$, a lack of water for full hydration for an anhydrite mass fraction between $0 \cdot 2$ and 0.65 is expected.

\section{Hydration kinetics}

Calorimetric measurements of the four mixes with different w/b ratios are shown in Figure 3. The initial period $(0-0.5 \mathrm{~h})$ was found to be similar in all systems but the heat observed in this period was certainly influenced by the heat introduced by external mixing (Wadsö et al., 2016). This initial period was followed by a short induction period of about $2.5 \mathrm{~h}$. During the first $8 \mathrm{~h}$, the heat generated over time was very similar in all systems. A slight increase in the acceleration of hydration in the W4 system was more pronounced for the T3 samples. This can be explained by the decrease in w/b ratio leading to an acceleration of early hydration. A reduction in water is expected to lead to a higher $\mathrm{pH}$ in the pore solution, which causes faster dissolution of the clinker phases, as has also been observed in the case of Portland cement (Danielson, 1962). As indicated by the cumulative heat curves after $8 \mathrm{~h}$, a decrease in $w / b$ ratio led to a reduction of the extent of hydration. This can be explained by a lack of water for hydration and/or the filling of space by hydrates, which limits further hydration as observed in blended Portland cement (Berodier and Scrivener, 2015; Glasser et al., 2001). The heat generated in the $\mathrm{T} 3$ and $\mathrm{T} 7$ systems was different in origin: in T5 it was mainly due to the formation of ettringite and in T3 to ettringite and sulfate-AFm. In the thermal power curves 
shown in Figure 3, the first peak appeared in all systems at about $5 \mathrm{~h}$ followed by an intense peak in the T3 system and a less intense peak in the T5 system, corresponding to the dissolution of cement phases and the precipitation of hydrates. Continuous in situ XRD measurements with hydration time may be helpful in future studies to determine the assignments of these peaks in more detail, as proposed by Jansen et al. (2012).

\section{X-ray diffraction and thermogravimetric analysis}

Figure 4 shows experimental diffraction patterns for samples $\mathrm{T} 3$ and $\mathrm{T} 5$ with a w/b ratio of 0.72 . In the T5W7 system (Figure 4(b)), the CA phase reacted quickly and was fully consumed after $12 \mathrm{~h}$ (see the diffraction peak at about $30^{\circ}$ ). The anhydrite started to react significantly at $5 \mathrm{~h}$. After $1 \mathrm{~d}$, hydration slowed down, leaving some unreacted anhydrite in the system (see the (021) diffraction peak at about $31 \cdot 4^{\circ}$ ). As $\mathrm{CA}$ and anhydrite dissolved, the formation of ettringite as

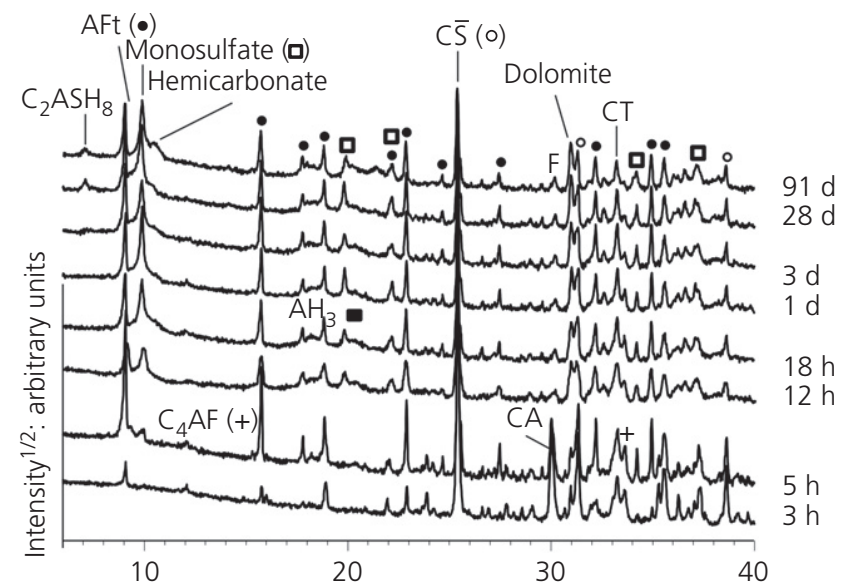

(a)

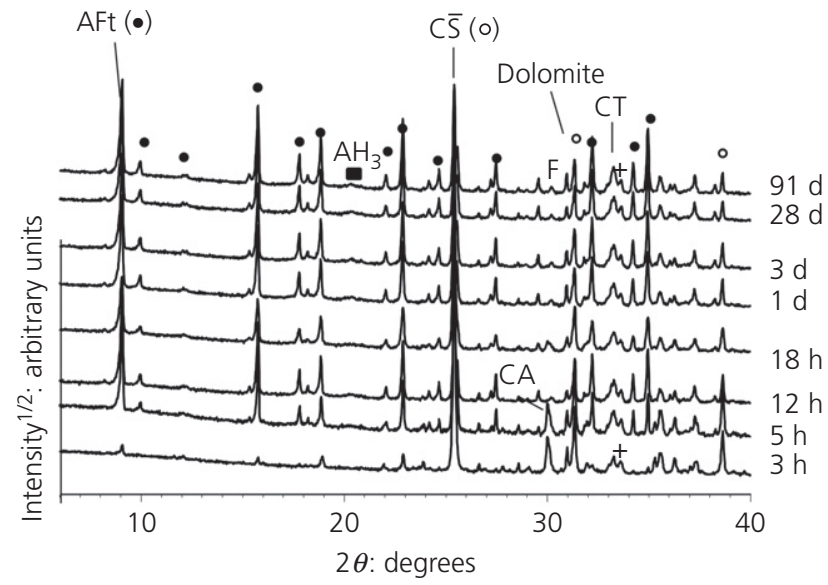

(b)

Figure 4. Diffraction patterns of (a) T3W7 and (b) T5W7 between 6 and $40^{\circ}, \mathrm{CuK}_{\alpha}$ the main hydration product was observed. Some broad reflections of $\mathrm{AH}_{3}$ were also detected but, as previously reported (Gosselin et al., 2010), $\mathrm{AH}_{3}$ is not well crystallised and is
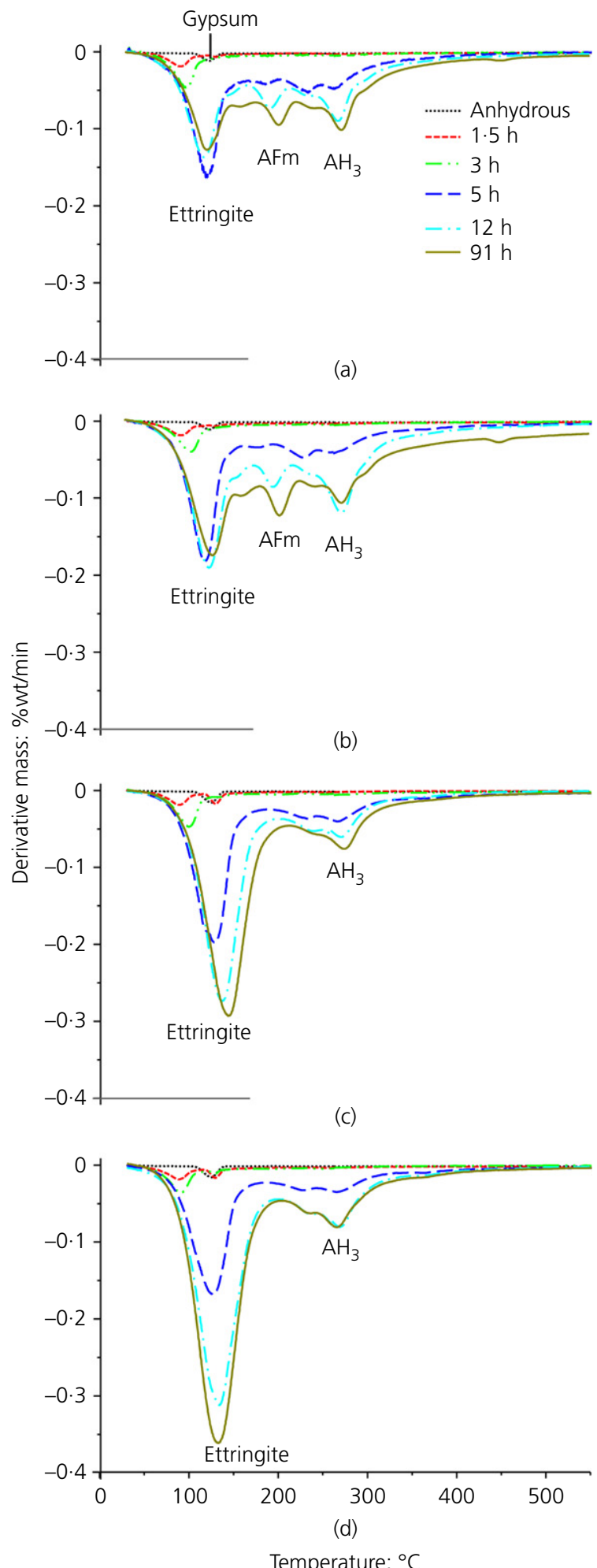

Figure 5. Differential TGA data for (a) T3W4, (b) T3W7, (c) T5W4 and (d) T5W7 pastes 
difficult to characterise using XRD. TGA is more appropriate to follow this phase.

The differential TGA curves for T5W7 are presented in Figure 5(d) and the assignments are based on the work of Lothenbach et al. (2015). Ettringite was already detected after $1.5 \mathrm{~h}$ and its quantity increased with time, as hydration proceeded. As for the ettringite, the amount of aluminium hydroxide $\left(\mathrm{Al}(\mathrm{OH})_{3}\right)$ increased rapidly until $12 \mathrm{~h}$.

In T5W7, the CA phase reacted with anhydrite to form ettringite and aluminium hydroxide according to Reaction I. The T5W4 system was similar to T5W7 but the decreased w/b ratio led to a reduction of the extent of hydration of CA and anhydrite. According to the thermodynamic calculations (Figure 2), a w/b ratio of 0.54 is needed for complete hydration. As shown by differential TGA (Figure 5(c)), the amount of ettringite in T5W4 was much less than in T5W7 due to a reduction of the extent of reaction of CA and anhydrite as insufficient water was available. XRD results (not shown) showed that, in T5W4, the dissolution of CA and anhydrite slowed down strongly after $12 \mathrm{~h}$ and beyond.

In comparison with the T5 system, XRD patterns (Figure 4(a)) of the T3W7 sample also include some reflections of AFm phases: monosulfate and hemicarbonate. From $3 \mathrm{~d}$ on, strätlingite $\left(\mathrm{C}_{2} \mathrm{ASH}_{8}\right)$ was present in the hydrate assemblage.

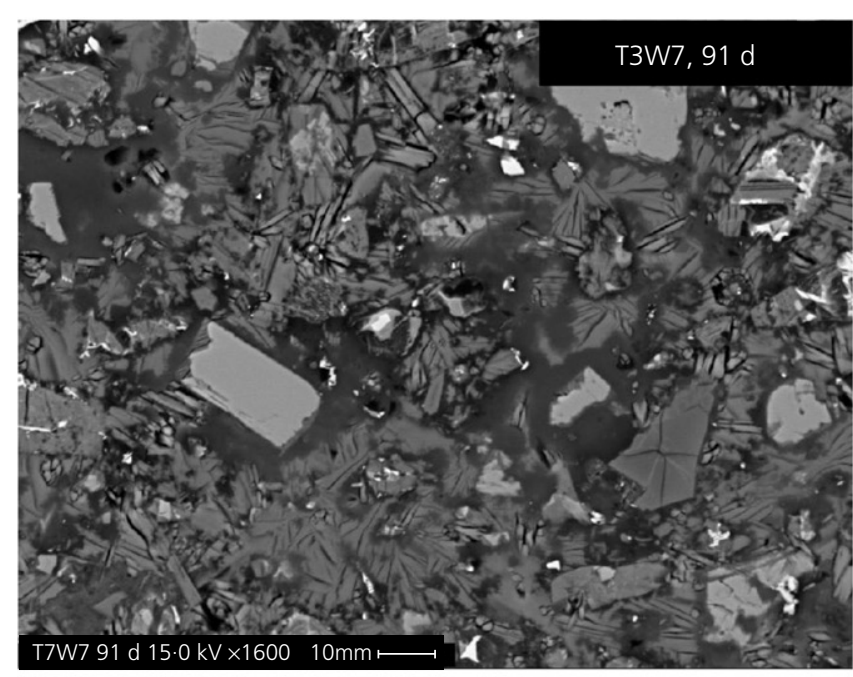

(a)

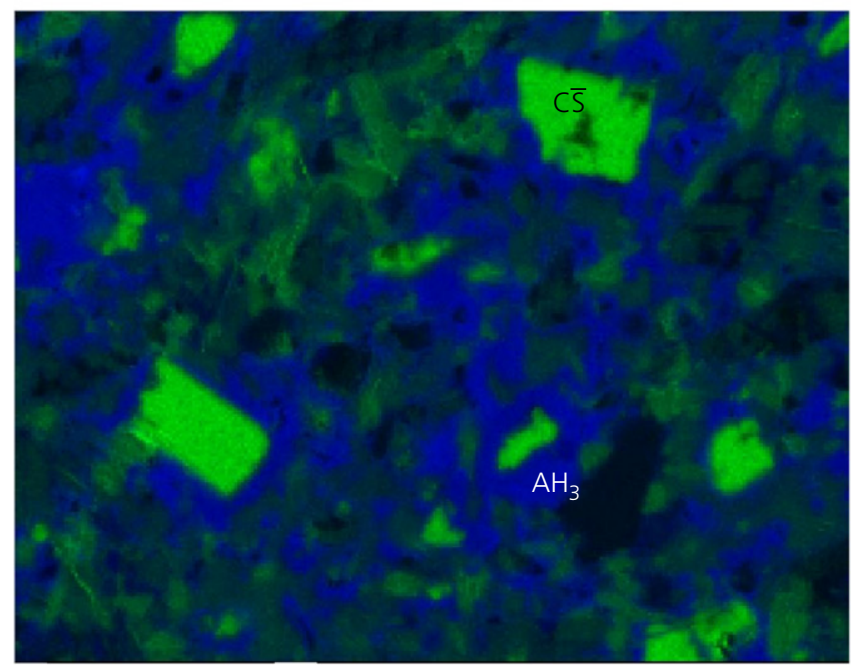

(c)

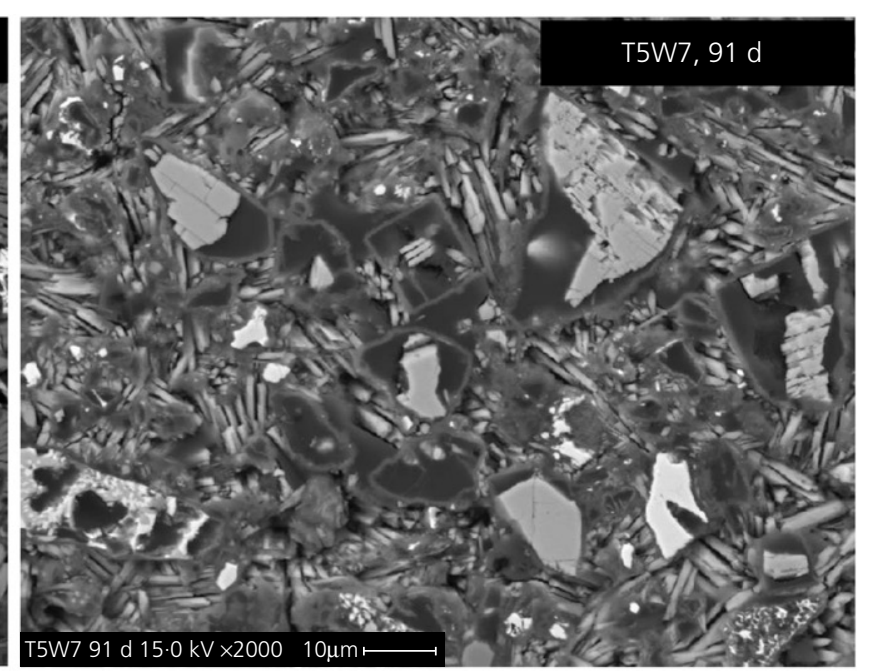

(b)

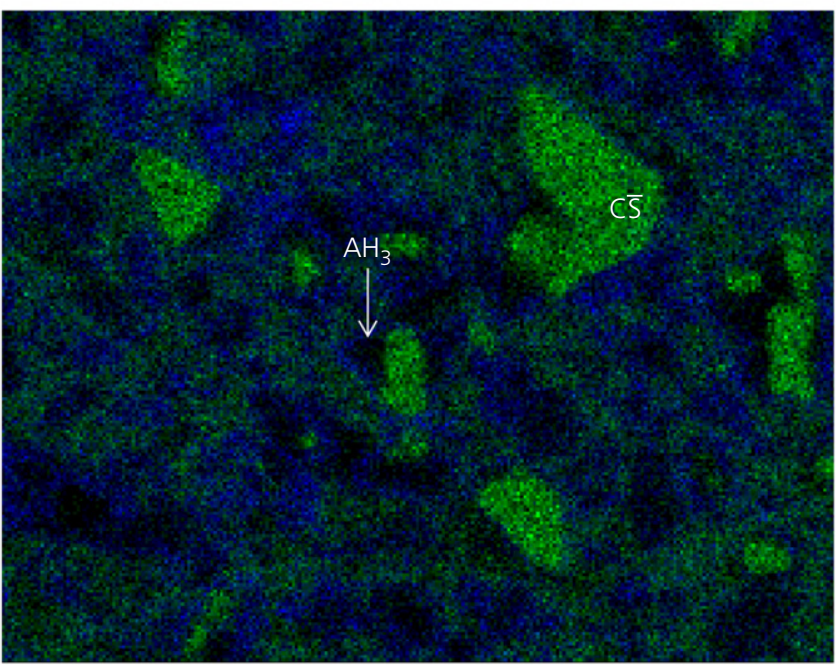

(d)

Figure 6. Backscattered images of (a) T3W7 and (b) T5W7 pastes hydrated at $91 \mathrm{~d}$. Element mapping is shown in (c) and (d): sulfur (green) and aluminium (blue). A full-colour version of this figure can be found on the ICE Virtual Library (www.icevirtuallibrary.com) 
The persistence of anhydrite in T3W7 was not expected according to thermodynamic modelling (Figure 2). This point will be discussed later with regard to the SEM results. In the differential TGA data shown in Figure 5(b), the peak at about $200^{\circ} \mathrm{C}$ can be assigned to AFm phase(s). Decomposition of the AFm phases in hydrated ordinary Portland cement usually presents a distinct endotherm between $185^{\circ} \mathrm{C}$ and $200^{\circ} \mathrm{C}$ (Lothenbach et al., 2015) but it is often not possible to distinguish the different AFm phases (De Weerdt et al., 2011). Due to small amount and peak overlaps, it was not possible to follow the thermal dehydration of strätlingite that should occur between $100^{\circ} \mathrm{C}$ and $210^{\circ} \mathrm{C}$ (Kuzel, 1976). The differential weight losses associated with ettringite and $\mathrm{AH}_{3}$ strongly increased between 3 and $5 \mathrm{~h}$. At $5 \mathrm{~h}$, the weight loss due to ettringite remained constant or slightly decreased with time whereas $\mathrm{AH}_{3}$ continued to increase and a peak associated with the presence of AFm phases appeared at $12 \mathrm{~h}$. Upon further hydration, the weight losses associated with $\mathrm{AFm}$ and $\mathrm{AH}_{3}$ slightly increased with time. The T3W4 system was similar to T3W7 but the decrease in w/b ratio led to a reduction of the extent of hydration and the presence of higher amounts of unreacted CA and anhydrite in the system (according to thermodynamic calculations a w/b ratio of at least 0.50 is needed for complete hydration). The peaks associated with minor phases $\left(\mathrm{C}_{2} \mathrm{~S}\right.$, phase $\mathrm{Q}, \mathrm{C}_{12} \mathrm{~A}_{7}$, ye'elimite and gypsum) were not observed after $3 \mathrm{~h}$, but were difficult to follow due to strong overlapping and the small amount involved. It was also noted that the $\mathrm{C}_{4} \mathrm{AF}$ phase seemed to react in the $\mathrm{T} 7$ system but not in $\mathrm{T} 5$ up to $91 \mathrm{~d}$.

\section{Backscattered electron images (SEM)}

Backscattered electron images of the polished surfaces of the T3W7 and T5W7 samples hydrated for $91 \mathrm{~d}$ (Figure 6) show the presence of anhydrite. The presence of anhydrite at $91 \mathrm{~d}$ in T3W7 and no clear evidence of further dissolution at later ages (similar XRD patterns at 28 and $91 \mathrm{~d}$ ) seem in contradiction with the thermodynamic modelling (Figure 2(b)). The SEM images revealed that anhydrite grains were embedded in a matrix consisting of $\mathrm{AH}_{3}$. The rims of $\mathrm{AH}_{3}$ seem to be larger in T3W7 than in T5W7. As suggested by Bayoux et al. (1990), the precipitation of alumina gel around anhydrite grains may lead to chemical blocking due to local interactions at the anhydrite/ $\mathrm{AH}_{3}$ interface and this explains why anhydrite does not fully dissolve. This is confirmed by the thermodynamic modelling, which indicated that the calcium sulfate/ $\mathrm{AH}_{3}$ combination is thermodynamically stable as long as no additional calcium oxide is available. Thus, calcium sulfate becomes chemically unstable and reacts only if the calcium sulfate can interact with solution in contact with CA or AFm phases.

A plot of sulfur/aluminium atomic ratios against calcium/aluminium atomic ratios from the EDX analyses of the hydrated paste (Figure 7), confirms the phase assemblage observed by XRD and TGA. In the T5 system, mainly $\mathrm{AH}_{3}$ and ettringite are present, whereas in the $\mathrm{T} 3$ system the

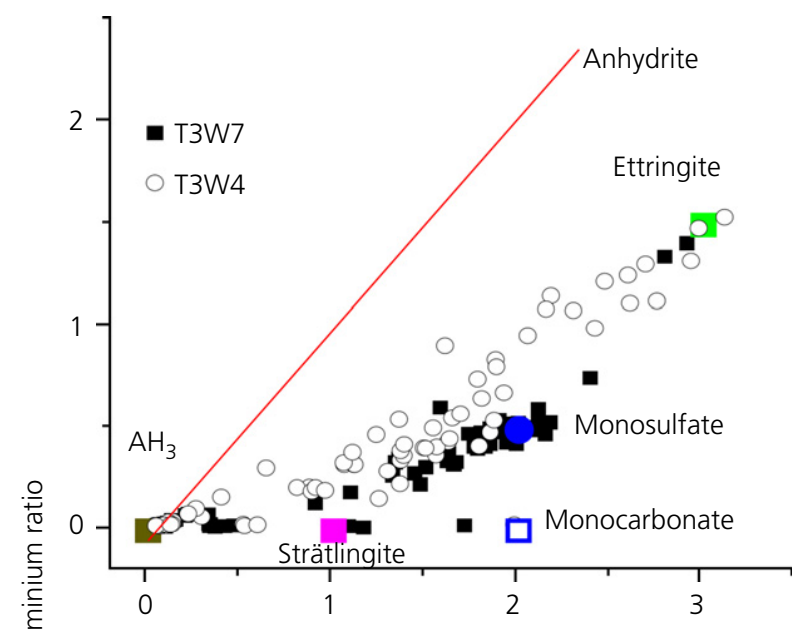

(a)

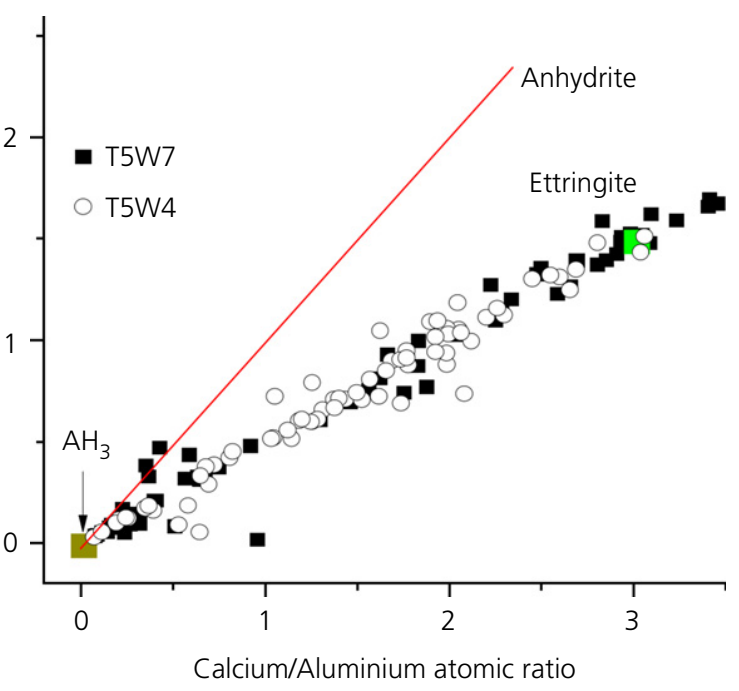

(b)

Figure 7. Sulfur/aluminium atomic ratio plotted against calcium/aluminium atomic ratio for individual $x$-ray microanalyses of the matrix of cement pastes at $91 \mathrm{~d}$

hydrate assemblage consists of a mixture of $\mathrm{AH}_{3}$, monosulfate and ettringite.

\section{Pore solution}

\section{Measured concentrations}

Pore solution analysis (Table 4) was performed only on the samples with the high w/b ratio (W7 samples) in order to be able to extract some solution from the samples. As shown by the previous methods of analysis, the main reaction started at around $1.5 \mathrm{~h}$ and thus the main variation in the concentration could be observed between 1.5 and $5 \mathrm{~h}$. During this period, the concentrations of potassium, sodium and sulfate increased in the T5W7 sample whereas aluminium decreased and calcium remained constant. The observed increase in alkali 
Table 4. Measured total concentrations in the pore solutions gained from T3W7 and T5W7

\begin{tabular}{|c|c|c|c|c|c|c|c|c|}
\hline Time & $\begin{array}{l}\text { Sodium: } \\
\mathrm{mmol} / \mathrm{l}\end{array}$ & $\begin{array}{c}\text { Potassium: } \\
\text { mmol/l }\end{array}$ & $\begin{array}{l}\text { Calcium: } \\
\mathrm{mmol} / \mathrm{l}\end{array}$ & $\begin{array}{c}\text { Aluminium: } \\
\mathrm{mmol} / \mathrm{l}\end{array}$ & $\begin{array}{l}\text { Sulfate: } \\
\text { mmol/l }\end{array}$ & $\begin{array}{c}\mathrm{OH}^{-}: \\
\mathrm{mmol} / \mathrm{l}^{\mathrm{a}}\end{array}$ & $\mathrm{pH}$ & $\begin{array}{l}\text { Bound } \\
\text { water }^{b}\end{array}$ \\
\hline \multicolumn{9}{|l|}{ T3W7 } \\
\hline $1.5 \mathrm{~h}$ & $6 \cdot 1$ & $1 \cdot 7$ & $15 \cdot 5$ & $4 \cdot 6$ & $13 \cdot 6$ & $1 \cdot 1$ & $11 \cdot 0$ & $1 \cdot 3$ \\
\hline $3 \mathrm{~h}$ & $6 \cdot 2$ & $2 \cdot 0$ & $10 \cdot 4$ & 11.4 & $3 \cdot 0$ & $1 \cdot 4$ & $11 \cdot 1$ & $2 \cdot 7$ \\
\hline $5 \mathrm{~h}$ & $20 \cdot 5$ & $19 \cdot 9$ & $2 \cdot 3$ & $6 \cdot 7$ & $13 \cdot 5$ & $5 \cdot 9$ & $11 \cdot 7$ & 14.9 \\
\hline $8 \mathrm{~h}$ & $22 \cdot 5$ & $20 \cdot 7$ & $3 \cdot 2$ & $5 \cdot 8$ & $19 \cdot 7$ & $4 \cdot 0$ & $11 \cdot 5$ & $24 \cdot 2$ \\
\hline $12 \mathrm{~h}$ & $23 \cdot 9$ & $22 \cdot 6$ & $2 \cdot 1$ & $5 \cdot 9$ & $19 \cdot 7$ & $5 \cdot 0$ & $11 \cdot 6$ & $24 \cdot 4$ \\
\hline $18 \mathrm{~h}$ & $24 \cdot 4$ & $22 \cdot 6$ & $1 \cdot 1$ & $7 \cdot 7$ & $15 \cdot 7$ & $7 \cdot 9$ & $11 \cdot 8$ & $24 \cdot 2$ \\
\hline $1 \mathrm{~d}$ & $23 \cdot 4$ & $19 \cdot 9$ & 0.9 & $7 \cdot 0$ & $13 \cdot 1$ & $8 \cdot 4$ & $11 \cdot 8$ & $25 \cdot 7$ \\
\hline $3 d$ & $30 \cdot 8$ & $27 \cdot 1$ & 0.8 & $7 \cdot 2$ & $18 \cdot 2$ & $13 \cdot 7$ & $12 \cdot 0$ & $26 \cdot 2$ \\
\hline $7 d$ & $30 \cdot 2$ & 24.9 & 0.5 & $6 \cdot 3$ & $16 \cdot 6$ & $13 \cdot 7$ & $12 \cdot 0$ & $26 \cdot 9$ \\
\hline $28 d$ & $30 \cdot 9$ & $24 \cdot 8$ & 0.7 & $9 \cdot 7$ & $9 \cdot 1$ & $25 \cdot 1$ & $12 \cdot 3$ & $27 \cdot 9$ \\
\hline \multicolumn{9}{|l|}{ T5W7 } \\
\hline $1.5 \mathrm{~h}$ & 10 & 2 & $19 \cdot 3$ & $4 \cdot 2$ & $18 \cdot 5$ & $1 \cdot 0$ & $10 \cdot 9$ & $1 \cdot 4$ \\
\hline $3 \mathrm{~h}$ & 11 & 2 & $12 \cdot 9$ & $7 \cdot 5$ & $9 \cdot 8$ & $1 \cdot 0$ & $10 \cdot 9$ & $2 \cdot 1$ \\
\hline $5 \mathrm{~h}$ & 23 & 13 & $9 \cdot 6$ & $2 \cdot 0$ & $22 \cdot 5$ & 0.9 & $10 \cdot 9$ & $13 \cdot 4$ \\
\hline $8 \mathrm{~h}$ & 27 & 16 & $11 \cdot 3$ & $0 \cdot 1$ & $28 \cdot 7$ & 0.7 & $10 \cdot 7$ & $26 \cdot 7$ \\
\hline $12 \mathrm{~h}$ & 30 & 18 & $12 \cdot 7$ & 0.4 & $33 \cdot 2$ & 0.4 & $10 \cdot 5$ & $26 \cdot 4$ \\
\hline $18 \mathrm{~h}$ & 30 & 18 & $12 \cdot 7$ & 0.5 & $33 \cdot 9$ & 0.5 & $10 \cdot 6$ & $27 \cdot 2$ \\
\hline $1 \mathrm{~d}$ & 28 & 16 & $13 \cdot 5$ & 0.4 & $32 \cdot 6$ & $1 \cdot 1$ & $10 \cdot 9$ & $28 \cdot 6$ \\
\hline $3 d$ & 31 & 18 & $16 \cdot 3$ & 0.1 & $37 \cdot 9$ & 0.7 & $10 \cdot 8$ & $29 \cdot 1$ \\
\hline $7 \mathrm{~d}$ & 31 & 16 & $18 \cdot 3$ & $<0.1$ & $39 \cdot 2$ & 0.4 & $10 \cdot 5$ & 30.6 \\
\hline $28 d$ & 34 & 17 & $19 \cdot 8$ & $<0.1$ & 41.9 & 0.3 & $10 \cdot 3$ & $31 \cdot 2$ \\
\hline
\end{tabular}

a Values for $\mathrm{OH}^{-}$refer to the free concentrations and are calculated from GEMS. The measured concentrations of silicon were below the detection limit of $0 \cdot 1 \mathrm{mM}$

${ }^{b}$ Bound water content expressed in grams per $100 \mathrm{~g}$ of dry binder determined from TGA measurements

and sulfate concentrations may be due to the decrease in pore solution volume as mixing water was consumed by the different hydration products (see bound water content deduced by TGA measurements in Table 4). The decrease in aluminium concentrations coincided roughly with the precipitation of ettringite from the XRD patterns (Figure 4). Afterwards, the pore solution equilibrated with ettringite and anhydrite. The situation was different in the T3W7 system - no decrease in aluminium concentration but a decrease in calcium concentration. The sulfate concentrations were significantly lower, indicating that the pore solution was no longer in equilibrium with ettringite and anhydrite as in $\mathrm{T} 5 \mathrm{~W} 7$ but with $\mathrm{AH}_{3}-\mathrm{AFm}$-ettringite. This difference was predicted well by the thermodynamic modelling (Figure 2(a)).

\section{Effective saturation indices}

The calculation of saturation indices from the concentrations measured in the pore solutions offers the possibility of independently assessing which solid phases may form from a thermodynamic point of view. In T5W7 (Figure 8(b)), the calculated effective saturation indices with respect to ettringite were relatively high, which agrees with the precipitation of ettringite observed by TGA and XRD. The pore solutions were slightly undersaturated at the beginning with respect to anhydrite and slightly oversaturated with respect to microcrystalline $\mathrm{AH}_{3}$, in agreement with the TGA and XRD results. However, after a few days, the solutions were undersaturated with respect to $\mathrm{AH}_{3}$, indicating that the $\mathrm{AH}_{3}$ dissolved under prolonged hydration. The dissolution of $\mathrm{AH}_{3}$ was not clearly observed by XRD and TGA but the kinetics of dissolution may be very slow. Initially, the solutions were also slightly saturated with respect to AFm phases (monosulfate and monocarbonate) and strätlingite, indicating that these phases could potentially form, but were not observed experimentally.

The saturation indices calculated for the system T3W7 (Figure 8(a)) were very different from those for T5W7. Initially, the pore solutions were strongly oversaturated with respect to $\mathrm{AH}_{3}$, indicating that $\mathrm{AH}_{3}$ could potentially form. However, experimentally, XRD and TGA indicated that no or very little $\mathrm{AH}_{3}$ was formed in this system initially (before $1.5 \mathrm{~h}$ ). After $1.5 \mathrm{~h}$, the pore solutions were still oversaturated with $\mathrm{AH}_{3}$ and slightly oversaturated with respect to ettringite and strätlingite. The saturation indices indicate that all these phases could potentially form upon prolonged hydration. Experimentally, ettringite was observed within the first few hours whereas strätlingite was only observed at about $3 \mathrm{~d}$. The pore solution was also in equilibrium with AFm phases (monosulfate, monocarbonate) as in T5W7 but, in this case, AFm phases were clearly detected by XRD and TGA. An important difference between the two systems is the strong undersaturation of the pore solution with respect to anhydrite in the case of T3W7. This is in apparent contradiction to the XRD data, which showed that anhydrite was still present in the system at a later age. As discussed earlier, the presence of 


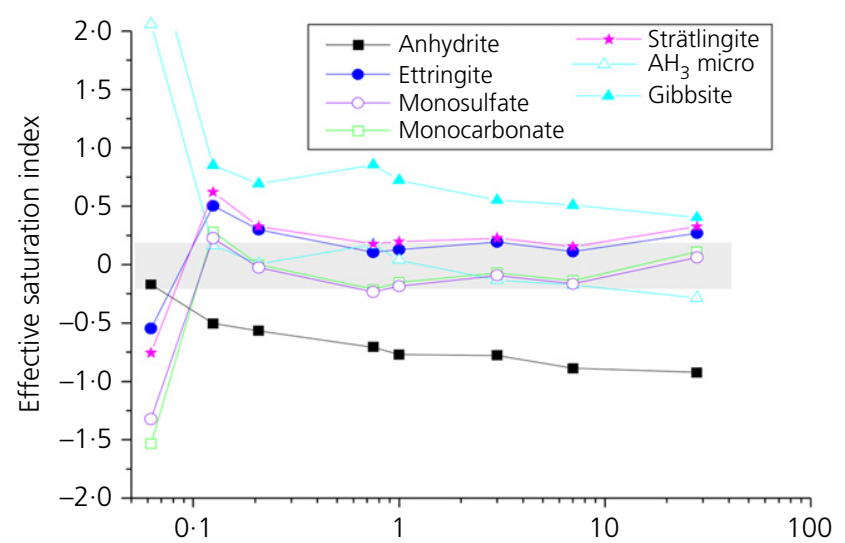

(a)

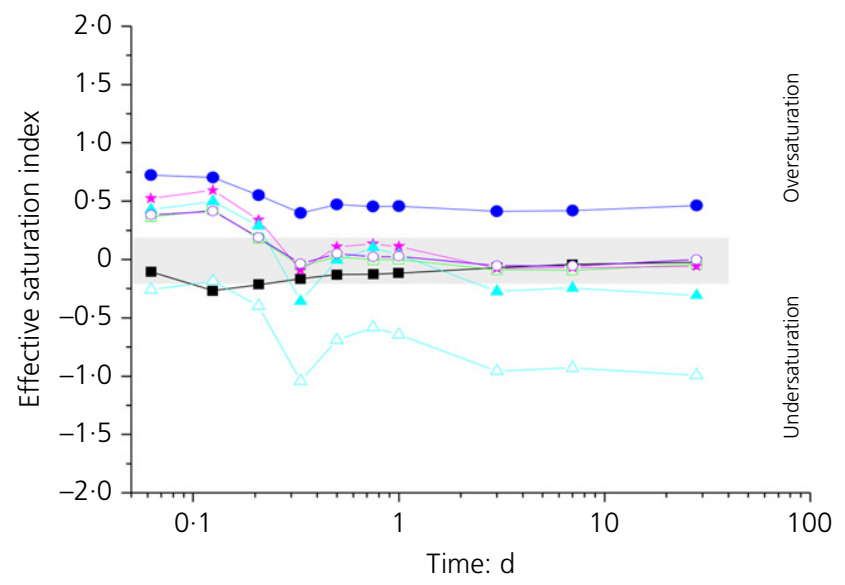

(b)

Figure 8. Effective saturation indices of anhydrite, ettringite, AFm phases (monosulfate, monocarbonate), strätlingite and $\mathrm{AH}_{3}$ micro of hydrated pastes (a) T3W7 and (b) T5W7 as a function of time. The shadowed area indicates saturation

$\mathrm{AH}_{3}$ around the anhydrite particle, as observed by SEM, impeded further dissolution of anhydrite.

\section{Thermodynamic modelling of the hydration process}

\section{Kinetic input in the thermodynamic model}

By combining experimental data of the dissolution of the clinker phases as a function of time with a thermodynamic equilibrium model that assumes equilibrium between the solution and the hydrates, the hydrates formed can be calculated as a function of time. The calculated degree of dissolution of the CA and anhydrite phases based on Rietveld XRD data was fitted by a decaying exponential function after $2.5 \mathrm{~h}$. (Figure 9). In order to take into account the partial dissolution of anhydrite in the system, based on XRD data, for the T3 and T5 systems, hydration degrees of anhydrite of about 65 and $60 \mathrm{wt} \%$ respectively were chosen; this led to a good estimation of the amount of ettringite at $91 \mathrm{~d}$ using thermodynamic modelling (Figure 9(b)). The conversion of anhydrite to gypsum was also prevented as the experimental data did not

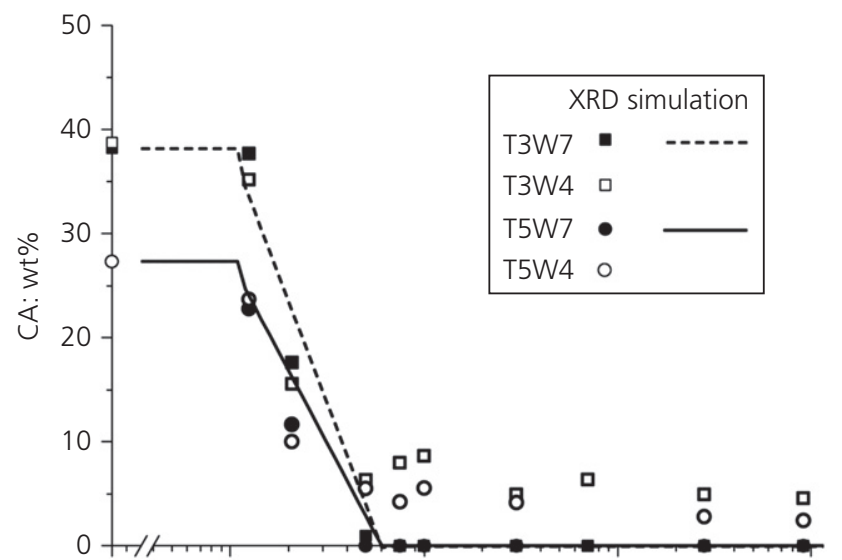

(a)

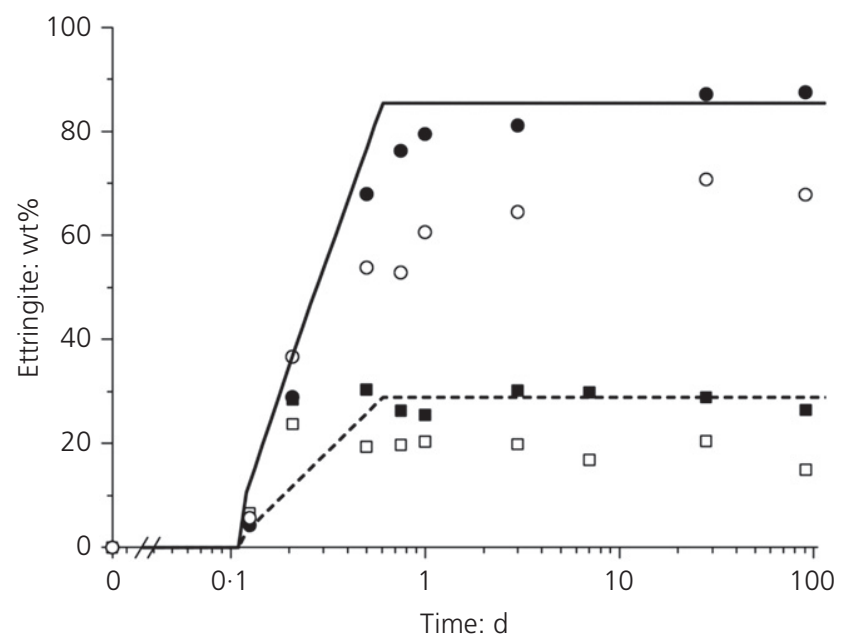

(b)

Figure 9. Amount of CA used as input in the thermodynamic model (a) and ettringite (b) deduced by XRD/Rietveld analysis as a function of hydration time. Lines refer to the results of thermodynamic modelling

show the occurrence of secondary gypsum, although thermodynamically it was expected.

The unreacted phases in Figure 10 refer to $\mathrm{CT}, \mathrm{C}_{3} \mathrm{FT}, \mathrm{Fe}_{3} \mathrm{O}_{4}$, $\mathrm{C}_{2} \mathrm{AF}$, dolomite, quartz and $\mathrm{C}_{2} \mathrm{AS}$. The other phases $\left(\mathrm{C}_{2} \mathrm{~S}\right.$, phase $\mathrm{Q}, \mathrm{C}_{12} \mathrm{~A}_{7}$, ye'elimite and gypsum) were assumed to react after $2.5 \mathrm{~h}$ as the peaks were not observed by XRD although their small amounts and peak overlaps did not permit their kinetics to be followed. Based on Rietveld XRD data, it was also assumed that $\mathrm{C}_{4} \mathrm{AF}$ did not react in $\mathrm{T} 5$ and around $40 \%$ reacted in $\mathrm{T} 3$.

\section{Development of the hydrate assemblage}

Thermodynamic modelling of the two systems is shown in Figure 10. In the T5W7 system, the modelling indicates that different hydrates were formed upon dissolution of the 


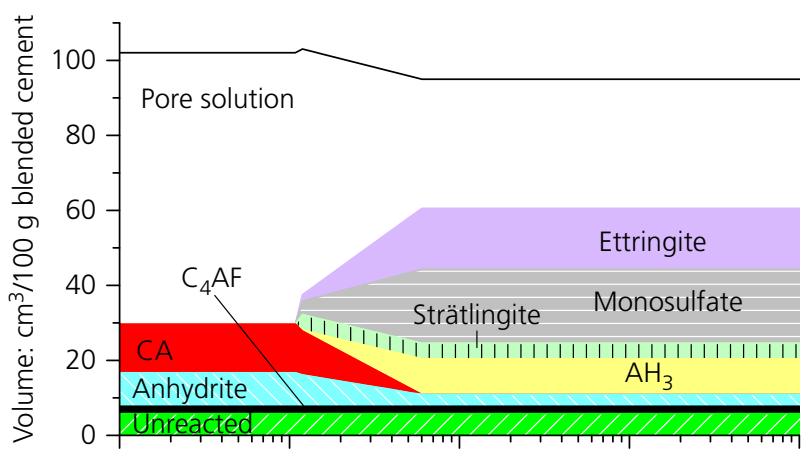

(a)

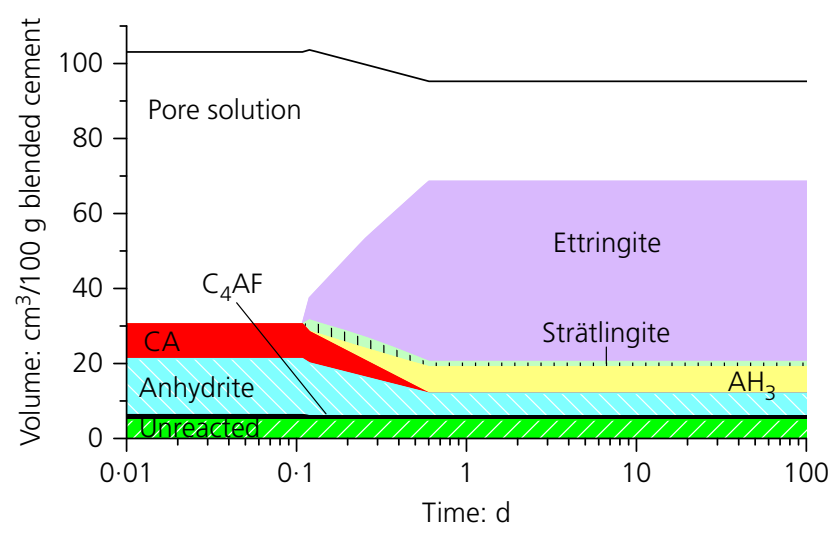

(b)

Figure 10. Modelled changes during the hydration of (a) T3W7 and (b) T5W7 as a function of time. Volume expressed as $\mathrm{cm}^{3} / 100 \mathrm{~g}$ of unhydrated blended cement. Phases with a volume below $1 \mathrm{~cm}^{3}\left(C_{2} S\right.$, phase $Q, C_{12} A_{7}$, ye'elimite and gypsum) are not shown in the figure, for clarity

anhydrous phase; initially, mainly ettringite and $\mathrm{AH}_{3}$. When the sulfates were consumed, the amount of ettringite and $\mathrm{AH}_{3}$ in the system did not change any further. A small amount of strätlingite was predicted; this was not be detected by XRD and TGA, probably because its quantity was below the detection limit.

In the T3W7 system, the thermodynamic model predicts that as CA is reacting, ettringite, monosulfate and $\mathrm{AH}_{3}$ precipitate; this was observed by TGA and XRD (Figures 4 and 5). In agreement with the XRD data, strätlingite is predicted at later ages. The amount of ettringite deduced by XRD was in the same range as the calculated quantities (Figure 9(b)). However, the presence of ill-crystallised phases such as $\mathrm{AFm}$ and $\mathrm{AH}_{3}$ were considered part of the $\mathrm{x}$-ray amorphous content and did not permit a quantitative comparison with the modelling to validate the control files.

\section{Conclusion}

The aim of this study was to characterise, quantify and model the hydration of commercial CAC blended with anhydrite at different $w / b$ ratios. The phase assemblage was found to depend strongly on the CAC/anhydrite ratio. In the T5 system (50 $\mathrm{wt} \%$ of anhydrite, $50 \mathrm{wt} \% \mathrm{CAC}$ ), the phase assemblage was relatively simple with the formation of ettringite and $\mathrm{AH}_{3}$ phases. In the T3 system (30 wt $\%$ of anhydrite, $70 \mathrm{wt} \% \mathrm{CAC}$ ), less ettringite was formed as less calcium sulfate was available. In addition to ettringite and $\mathrm{AH}_{3}$, monosulfate was present. At later ages, the presence of strätlingite and hemicarbonate was observed. Based on the experimentally observed hydration degrees of CA and anhydrite, the thermodynamic model predicted the hydrate assemblage well. In contrast to the modelling, anhydrite persisted even at low calcium sulfate contents, as the precipitation of $\mathrm{AH}_{3}$ around anhydrite grains seems to have led to a chemical blocking. A reduction in the extent of hydration was observed at the lower $w / b$ ratio. This can be explained by two factors - a lack of sufficient water for complete hydration and a reduction in the availability of space.

\section{Acknowledgements}

The authors acknowledge B. Ingold, L. Brunetti L and A. Steffen for experimental support in the laboratory and M. Ben Haha and F. Deschner for performing the SEM analyses.

\section{REFERENCES}

AFNOR (Association Française de Normalisation) (2009) NF EN 196-3+A1: 2009. Methods of testing cement, Part 3: Determination of setting times and soundness. AFNOR, La Plaine Saint-Denis, France.

Allmann R (1977) Refinement of the hybrid layer structure $\left[\mathrm{Ca}_{2} \mathrm{Al}(\mathrm{OH})_{8}\right]^{+}\left[1 / 2 \mathrm{SO}_{4} 3 \mathrm{H}_{2} \mathrm{O}\right]^{-}$. Neues Jahrbuch für Mineralogie 1977(3): 136-144.

Bayoux JP, Bonin A, Marcdargent S and Verschaeve M (1990) Study of the hydration properties of aluminous cement and calcium sulphate mixes. In Proceedings of the International Symposium on Calcium Aluminate Cement (Mangabhai RJ (ed.)). E \& FN Spon, London, UK, pp. 320-334.

Berodier E and Scrivener KL (2015) Evolution of pore structure in blended systems. Cement and Concrete Research 73: 25-35, https://doi.org/10.1016/j.cemconres.2015.02.025.

Bizzozero J, Gosselin C and Scrivener KL (2014) Expansion mechanisms in calcium aluminate and sulfoaluminate systems with calcium sulfate. Cement and Concrete Research 56: 190-202, https://doi.org/ 10.1016/j.cemconres.2013.11.011.

Christensen AN and Lehmann MS (1984) Neutron powder diffraction profile refinement studies on $\mathrm{Ca}_{11.3} \mathrm{Al}_{14} \mathrm{O}_{32.3}$ and $\mathrm{CaClO}\left(\mathrm{D}_{0.88} \mathrm{H}_{0.12}\right)$. Journal of Solid State Chemistry 51(2): 196-204.

Colville AA and Geller S (1971) The crystal structure of brownmillerite, $\mathrm{Ca}_{2} \mathrm{FeAlO}_{5}$. Acta Crystallographica Section B 27(12): 2311-2315.

Danielson UH (1962) Heat of hydration of cement as affected by water-cement ratio. In Proceedings of the 4th International Symposium on the Chemistry of Cement (Carlson ET, Steinour HH, Newman ES and Catton MD (eds)). National Bureau of Standards, Washington, DC, USA, Monograph 43, vol. I, paper IV-S7, pp. 519-526.

De la Torre AG, Lopez-Olmo MG, Alvarez-Rua C, Garcia-Granda S and Aranda MAG (2004) Structure and microstructure of gypsum and its relevance to Rietveld quantitative phase analyses. Powder Diffraction 19(3): 240-246. 
De Weerdt K, Ben Haha M, Le Saout G et al. (2011) Hydration mechanisms of ternary Portland cements containing limestone powder and fly ash. Cement and Concrete Research 41(3): 279-291.

Dilnesa BZ, Lothenbach B, Renaudin G, Wichser A and Kulik D (2014) Synthesis and characterization of hydrogarnet $\mathrm{Ca}_{3}\left(\mathrm{Al}_{x} \mathrm{Fe}_{1-x}\right)_{2}\left(\mathrm{SiO}_{4}\right)_{y}(\mathrm{OH})_{4(3-y)}$. Cement and Concrete Research 59: 96-111, https://doi.org/10.1016/j.cemconres.2014.02.001.

Effenberger H, Kirfel A and Will G (1983) Untersuchungen zur Elektronendichteverteilung im Dolomit $\mathrm{CaMg}\left(\mathrm{CO}_{3}\right)_{2}$. Tschermaks Mineralogische und Petrographische Mitteilungen 31(1-2): 151-164 (in German).

EMPA (2017) http://www.empa.ch/web/s308/cemdata (accessed 05/07/2017).

Füllmann T, Walenta G, Bier T, Espinosa B and Scrivener K (1999) Quantitative Rietveld phase analysis of calcium aluminate cements. World Cement Research June 1999: 1-6.

GEMS (GEM Software) (2017) http://gems.web.psi.ch (accessed 05/07/2017).

Glasser FP, Zhang L and Zhou Q (2001) Reactions of aluminate cements with calcium sulphate. In Proceedings of the International Conference on Calcium Aluminate Cement (Mangabhai RJ and Glasser FP (eds)). IOM Communications, London, UK, pp. 551-564.

Gosselin C, Gallucci E and Scrivener K (2010) Influence of self-heating and $\mathrm{Li}_{2} \mathrm{SO}_{4}$ addition on the microstructural development of calcium aluminate cement. Cement and Concrete Research 40(10): 1555-1570.

Götz-Neunhoeffer F (2003) Quantitative phase analysis of various Fe-rich calcium aluminate cement clinkers by selective dissolution and XRPD. In Proceedings of the 11th International Congress on the Chemistry of Cement (Grieve G and Owens G (eds)). Document Transformation Technologies, Gauteng, South Africa, pp. 125-134 (CD-ROM).

Götz-Neunhoeffer F and Neubauer J (2004) Refined ettringite $\left(\mathrm{Ca}_{6} \mathrm{Al}_{2}\left(\mathrm{SO}_{4}\right)_{3}(\mathrm{OH})_{12} 26 \mathrm{H}_{2} \mathrm{O}\right)$ structure for quantitative X-ray diffraction analysis. Powder Diffraction 21(1): 4-11.

Hanic F, Handlovic M and Kapralik I (1980) The structure of a quaternary phase $\mathrm{Ca}_{20} \mathrm{Al}_{32-2 x} \mathrm{Mg}_{x} \mathrm{Si}_{x} \mathrm{O}_{68}$. Acta Crystallographica Section $B$ 36(12): 2863-2869.

Hawthorne FC and Ferguson RB (1975) Anhydrous sulphates. II. Refinement of the crystal structure of anhydrite. The Canadian Mineralogist 13(3): 289-292.

Hidalgo Lopez A, Garcia Calvo JL, Garcia Olmo J, Petit S and Cruz Alonso M (2008) Microstructural evolution of calcium aluminate cements hydration with silica fume and fly ash additions by scanning electron microscopy, and mid and near-infrared spectroscopy. Journal of the American Ceram Society 91(4): $1258-1265$

Hörkner W and Müller-Buschbaum HK (1976) Zur kristallstruktur von $\mathrm{CaAl}_{2} \mathrm{O}_{4}$. Journal of Inorganic and Nuclear Chemistry 38(5): 983-984 (in German).

Hummel W, Berner U, Curti E, Pearson FJ and Thoenen T (2002) NagralPSI Chemical Thermodynamic Data Base 01/01. Universal Publishers, Parkland, FL, USA.

Jansen D, Götz-Neunhoeffer F and Neubauer J (2011a) A remastered external standard method applied to the quantification of early OPC hydration. Cement and Concrete Research 41(6): 602-608.

Jansen D, Stabler C, Götz-Neunhoeffer F, Dittrich S and Neubauer J (2011b) Does ordinary Portland cement contain amorphous phase? A quantitative study using an external standard method. Powder Diffraction 26(1): 31-38.

Jansen D, Goetz-Neunhoeffer F, Lothenbach B and Neubauer J (2012) The early hydration of Ordinary Portland Cement
(OPC): an approach comparing measured heat flow with calculated heat flow from QXRD. Cement and Concrete Research 42(1): 134-138.

Jorgensen JD (1978) Compression mechanisms in alpha-quartz structures $-\mathrm{SiO}_{2}$ and $\mathrm{GeO}_{2}$. Journal of Applied Physics 49(11): 5473-5478.

Kulik DA, Wagner T, Dmytrieva SV et al. (2013) GEM-Selektor geochemical modeling package: revised algorithm and GEMS3K numerical kernel for coupled simulation codes. Computers \& Geosciences 17(1): 1-24.

Kuzel HJ (1976) Crystallographic data and thermal decomposition of synthetic gehlenite hydrate $2 \mathrm{CaO} \mathrm{Al}{ }_{2} \mathrm{O}_{3} \mathrm{SiO}_{2} 8 \mathrm{H}_{2} \mathrm{O}$. Neues Jahrbuch für Mineralogie 1976(7): 319-325.

Le Saout G, Lothenbach B, Hori A, Higuchi T and Winnefeld F (2013) Hydration of Portland cement with additions of calcium sulfoaluminates. Cement and Concrete Research 43: 81-94, https://doi.org/10.1016/j.cemconres.2012.10.011.

Lothenbach B (2010) Thermodynamic equilibrium calculations in cementitious systems. Materials and Structures 43(10): 1413-1433.

Lothenbach B (2014) Thermodynamic modelling of effect of time and silica on the conversion process. In Proceedings of the International Conference on Calcium Aluminates (Fentiman C, Mangabhai RJ and Scrivener K (eds)). IHS BRE Press, Watford, UK, pp. 153-164.

Lothenbach B and Winnefeld F (2006) Thermodynamic modelling of the hydration of Portland cement. Cement and Concrete Research 36(2): 209-226.

Lothenbach B, Matschei T, Möschner G and Glasser FP (2008) Thermodynamic modelling of the effect of temperature on the hydration and porosity of Portland cement. Cement and Concrete Research 38(1): 1-18.

Lothenbach B, Pelletier-Chaignat $L$ and Winnefeld F (2012) Stability in the system $\mathrm{CaO}-\mathrm{Al}_{2} \mathrm{O}_{3}-\mathrm{H}_{2} \mathrm{O}$. Cement and Concrete Research 42(12): 1621-1634.

Lothenbach B, Durdziński PT and De Weerdt K (2015) Thermogravimetric analysis. In A Practical Guide to Microstructural Analysis of Cementitious Materials (Scrivener K, Snellings R and Lothenbach B (eds)). CRC Press, Boca Raton, FL, USA, pp. 177-211.

Lutz H and Bayer R (2010) Dry mortars. In Ullmann's Encyclopedia of Industrial Chemistry (Elvers B (ed.)). Wiley-VCH, Weinheim, Germany, pp. 541-579.

Matschei T, Lothenbach B and Glasser FP (2007) Thermodynamic properties of Portland cement hydrates in the system $\mathrm{CaO}-\mathrm{Al}_{2} \mathrm{O}_{3}-$ $\mathrm{SiO}_{2}-\mathrm{CaSO}_{4}-\mathrm{CaCO}_{3}-\mathrm{H}_{2} \mathrm{O}$. Cement and Concrete Research 37(9): 1379-1410.

O'Connor BH and Raven MD (1988) Application of the Rietveld refinement procedure in assaying powdered mixtures. Powder Diffraction 3(1): 2-6.

Odler I (2000) Special Inorganic Cements: Modern Concrete Technology 8. E \& FN Spon, London, UK.

Pelletier L, Winnefeld F and Lothenbach B (2010) The ternary system Portland cement-calcium sulphoaluminate clinker-anhydrite: hydration mechanism and mortar properties. Cement \& Concrete Composites 32(7): 497-507.

Pöllmann H (2001) Mineralogy and crystal chemistry of calcium aluminate cement. In Proceedings of the International Conference on Calcium Aluminate Cement (Mangabhai RJ and Glasser FP (eds)). IOM Communications, London, UK, pp. 79-119.

Redhammer GJ, Tippelt G, Roth G and Amthauer G (2004) Structural variations in the brownmillerite series $\mathrm{Ca}_{2}(\mathrm{Fe}, \mathrm{Al}) \mathrm{O}_{5}$ : single-crystal $\mathrm{X}$-ray diffraction at $25^{\circ} \mathrm{C}$ and high temperature X-ray powder diffraction $\left(25^{\circ} \mathrm{C}<\mathrm{T}<1000^{\circ} \mathrm{C}\right)$. American Mineralogist $89(2-3)$ : 405-420. 
Rodriguez-Carvajal J, Vallet-Regi M and Calbet JG (1989) Perovskite threefold superlattices: a structure determination of the $\mathrm{A}_{3} \mathrm{M}_{3} \mathrm{O}_{8}$ phase. Materials Research Bulletin 24(4): 423-430.

Saalfeld H and Depmeier W (1972) Silicon-free compounds with sodalite structure. Crystal Research and Technology 7(1-3): 229-233.

Sasaki S (1997) Radial distribution of electron density in magnetite, $\mathrm{Fe}_{3} \mathrm{O}_{4}$. Acta Crystallographica Section B 53(5): 762-766.

Sasaki S, Prewitt CT and Bass JD (1987) Orthorhombic perovskite $\mathrm{CaTiO}_{3}$ and $\mathrm{CdTiO}_{3}$ : structure and space group. Acta Crystallographica C43(9): 1668-1674.

Stabler C, Götz-Neunhoeffer F, Neubauer J, Estival J and Taquet P (2011) In-situ investigation of calcium aluminate cement-based dry-mix mortars with improved shelf life properties. In Tagung Bauchemie GDCh Monograph (Schmidt-Döhl F and Deckelmann G (eds)). GDCh, Frankfurt am Main, Germany, vol. 44, pp. 68-73.

Swainson IP, Dove MT, Schmahl WW and Putnis A (1992) Neutron powder diffraction study of the akermanite-gehlenite solid solution series. Physics and Chemistry of Minerals 19(3): 185-195.
Tsurumi T, Hirano Y, Kato H, Kamiya T and Daimon M (1994) Crystal structure and hydration of belite. Ceramic Transactions 40: 19-25.

Wadsö L (2005) Applications of an eight-channel isothermal conduction calorimeter for cement hydration studies. Cement International 3(5): 94-101.

Wadsö L, Winnefeld F, Riding $\mathrm{K}$ and Sandberg P (2016) Calorimetry. In A Practical Guide to Microstructural Analysis of Cementitious Materials (Scrivener K, Snellings R and Lothenbach B (eds)). CRC Press, Boca Raton, FL, USA, pp. $37-74$

Wagner T, Kulik DA, Hingerl FF and Dmytrieva SV (2012) GEM-Selektor geochemical modeling package: TSolMod library and data interface for multicomponent phase models. Canadian Mineralogist 50(5): 1173-1195.

Winnefeld F and Lothenbach B (2010) Hydration of calcium sulfoaluminate cements - experimental findings and thermodynamic modeling. Cement and Concrete Research 40(8): 1239-1247. 